\title{
薬学的視点からのウイルス学研究一肝炎ウイルス複製阻害化合物の同定とその作用機序一
}

\author{
渡士幸一
}

\section{Antiviral Agents for Analyzing Virus Life Cycle: Chemical Genetics for Virology}

\author{
Koichi Watashi \\ Department of Virology II, National Institute of Infectious Diseases; 1-23-1 Toyama, \\ Shinjuku-ku, Tokyo 162-8640, Japan.
}

(Received July 30, 2013)

\begin{abstract}
Hepatitis C virus, which affects approximately 170 million people worldwide, is a major causative agent of hepatocellular carcinoma. Anti-HCV treatment is available with the combination of pegylated interferon and ribavirin, and newly approved protease inhibitors. However, because of the diverse anti-HCV efficacy among HCV genotypes and significant side effects, alternative anti-HCV agents are in great demand. Using cell-based systems supporting a part of or the whole HCV life cycle, we identified cyclosporin A, tamoxifen, and benzamide derivatives that inhibited the replication of HCV RNA or the production of infectious HCV particles. In this article, we summarize the mechanistic analyses of the HCV life cycle using these small molecules. Thus, chemical genetics is a powerful approach for revealing molecular mechanisms of the viral life cycle as well as for developing new antiviral agents.
\end{abstract}

Key words - hepatitis C virus (HCV); hepatitis B virus (HBV); replication; infection; cyclosporine; cyclophilin

\section{1. はじめに}

基礎ウイルス学研究の目標は, ウイルス感染増殖 系というモデル系を用いて新たなウイルス学・生物 学原理を明らかにすること，ウイルスをべクターな ごのツールとして新たな疾患治療法や実験技術に資 するテクノロジーを開発すること, など様々挙げら れるが, ウイルス感染が引き起こす疾患の治療/予 防法を開発することもその 1 つである. ウイルス学 の解析によって多くの研究成果が毎年論文として発 表され，例えば PubMed で「ウイルス」のキーワー ドを含む 2012 年の論文数を検索すると 8 万報以上 が列挙される。しかしながら新規抗ウイルス剂開発 例は学術雑誌掲載のそれに比べて，もちろん極端に 少ないのが現状である。 どのようにすれば基礎ウイ ルス学が効率よく新薬開発に貢献できるのであろう か? この問いが本研究の出発点である. 本稿では 現在われわれが試みている，低分子化合物を利用し

The author declares no conflict of interest.

国立感染症研究所ウイルス第二部（†162-8640 東京都 新宿区戸山 1-23-1)

e-mail: kwatashi@nih.go.jp

本総説は, 日本薬学会第 133 年会シンポジウム S28302 で発表した内容を中心に記述したものである.
たウイルス学研究に関して述べる。本手法を用いる ことで，ウイルス複製増殖の分子メカニズムを明ら かにできるだけでなく，効率よく創薬に貢献できる 可能性を考えている. 本稿でその一端を簡単に紹介 する.

\section{HCV 感染と現行の治療法}

$\mathrm{C}$ 型肝炎ウイルス（hepatitis $\mathrm{C}$ virus; HCV）感 染は肝硬変, 肝細胞がん発症の主な原因であり, 特 にわが国では肝がんの約 $80 \%$ HCV 感染を土台 としていることから, 肝がん発症の阻止には抗 $\mathrm{HCV}$ 療法の確立が最も有効な手段の 1 つであるこ とは明らかである.1 ${ }^{1}$ 抗 $\mathrm{HCV}$ 療法には従来よりぺ グインターフェロンとリバビリンの併用療法が主な 役割を果たし，また最近プロテアーゼ阻害剤が新た に認可され，これらを中心とした抗ウイルス療法が

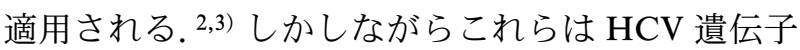
型により有効性が異なること, 特にインターフェロ ン療法ではときに重篤な副作用がみられること，プ ロテアーゼ阻害剤に対しては薬剤耐性遺伝子の出現 が否定できないことから，これに替わる抗 $\mathrm{HCV}$ 剂 開発が重要な課題である。われわれは「HCVが宿 主細胞内でどのようにして増えるのか」を明らかに 
するとともに，「HCV 感染増殖を阻止する手段」 を見つけることを目的として研究を行っている.

\section{HCV 生活環}

本稿では低分子化合物による HCV 生活環の解析 に関して述べるので，まずはじめに HCV 生活環に ついて理解しておく必要がある [Fig. 1(A)]. HCV は宿主細胞である肝細胞に，細胞表面の CD81， scavenger receptor class B type I (SR-BI), claudin 1, occuludin を含む複数の受容体を介して「吸着」「侵 入」する. ${ }^{4)}$ 侵入は主にクラスリン依存性エンドサ イトーシスを介しており, 輸送小胞内でウイルスと 細胞との膜融合の後，キャプシド/ウイルスゲノム RNA 複合体が細胞質へと侵入する。 ウイルスゲノ ム RNA がキャプシドから脱款することにより，こ れを鋳型としてリボソームでウイルス前駆体ポリタ ンパク質が「翻訳」される.5) ウイルス前駆体ポリ タンパク質は宿主及び自身のプロテアーゼにより成 熟型ウイルスタンパク質にプロセシングされる，産 生されたウイルスタンパク質の働きにより，主に小 胞体近辺に形成される複製複合体内でウイルスゲノ ム RNA を鋳型として相補鎖のウイルスゲノム RNA が「RNA 複製」される。 $\left.{ }^{6}\right)$ 十分に翻訳及び RNA 複製が行われた後，ウイルスタンパク質とウ イルスゲノム RNA が主に脂肪滴周辺で「粒子形成」 し，これは「膜輸送」を経て細胞外へと「放出」さ れる. ${ }^{7)}$ 本稿では便宜的に生活環を 1) 吸着，侵入を 含む $\mathrm{HCV}$ 感染「初期過程」，2) 翻訳，プロセシン グ，RNA 複製からなる「中期過程」，3)さらに粒 子形成，放出を含めた「後期過程」に分けて考える. 抗ウイルス剤開発には着目する化合物がどのステッ プを標的とするかが重要となる.

\section{HCV 研究に用いられる実験系}

$\mathrm{HCV}$ 生活環解析に欠かせない 3 つの実験系とし て HCV レプリコンシステム [Fig. 1(B)] ${ }^{8)} \mathrm{HCV}$ シュード粒子系（HCVpp システム） [Fig. 1(C)], 9,10) HCV 粒子産生系（HCVcc システム）[Fig. 1(D)], 11-13) に関して説明する。これらはそれぞれ HCV 生活環 のどのステップを解析できるかが異なっており，抗 $\mathrm{HCV}$ 剤の標的ステップの切り分けなどに有用であ る. 少し専門分野的な話を含むので，大枠のみ理解 されたい読者はこのまま次項へと読み進んで頂きた い.

前項で述べた HCV 生活環を再現する培養細胞系
はこのウイルスが発見された後，しばらく樹立でき なかったが，1999 年にドイツの Bartenschlager ら によって開発された HCV レプリコンシステムによ り，まず翻訳〜 RNA 複製を含む $\mathrm{HCV}$ 生活環中期 過程が解析できるようになった [Fig. 1(B) ]. ${ }^{8)} こ$ れは翻訳〜 RNA 複製に必要な HCV ゲノム上の領 域を含むキメラ RNA がヒト肝がん由来 Huh-7 細 胞内で自律複製している系であり，つまりこの細胞 内に存在する HCV タンパク質あるいは HCV ゲノ ム RNA を定量することにより翻訳〜 RNA 複製の 活性を調べることができる画期的な細胞系であっ た。このキメラ RNA にはウイルス粒子を構成する 構造タンパク質領域は含まれないことから RNA 複 製の後に粒子形成は行われない。一方 HCV 吸着, 侵入は 2003 年に開発された HCVpp システムで評 価できる.9,10)これは HCV エンベロープを外殼 に，ルシフェラーゼ遺伝子をゲノムに持つレトロウ イルスベクターベースのシュード粒子であり，ルシ フェラーゼ活性を指標に HCV エンベロープ依存的 な吸着，侵入が解析できる [Fig. 1(C)]。また後期 過程を含めた全 HCV 生活環の解析には HCV cc シ ステムを用いる [Fig. 1(D)]. 11-13)これは 2005 年 に脇田らを始めとするグループにより開発された系 であり，HCV 全長 RNA を Huh-7 細胞に導入する ことにより，培養上清に感染性 HCV 粒子を放出さ せ，これを再び Huh-7 細胞亜株に処理することに より感染が成立する系である，このシステムでは全 $\mathrm{HCV}$ 生活環が再現されているため, 後期過程も解 析することができる.

5. シクロスポリン及びタモキシフェンによる HCV ゲノム複製抑制作用

ここからが本題である。われわれはこのような $\mathrm{HCV}$ 生活環の分子機構解明のため, 及び新規抗 $\mathrm{HCV}$ 剂開発のため，低分子化合物を利用した解析 を行っている。まず HCV 生活環の一部あるいは全

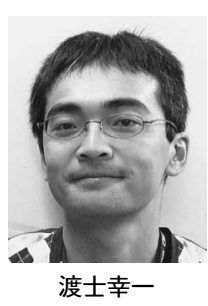

国立感染症研究所ウイルス第二部・主 任研究官 博士 (薬学)。1998 年京都 大学薬学部卒業. 博士号取得後, 京都 大学ウイルス研究所助手, 米国 NIH 客 員研究員などを経て，2009年より現職. 2011 年より東京理科大学理工学部客員 准教授併任.ささやかな研究チームを 主宰. 日本癌学会奨励賞, 日本ウイル 又学会杉浦奨励賞など受賞. 


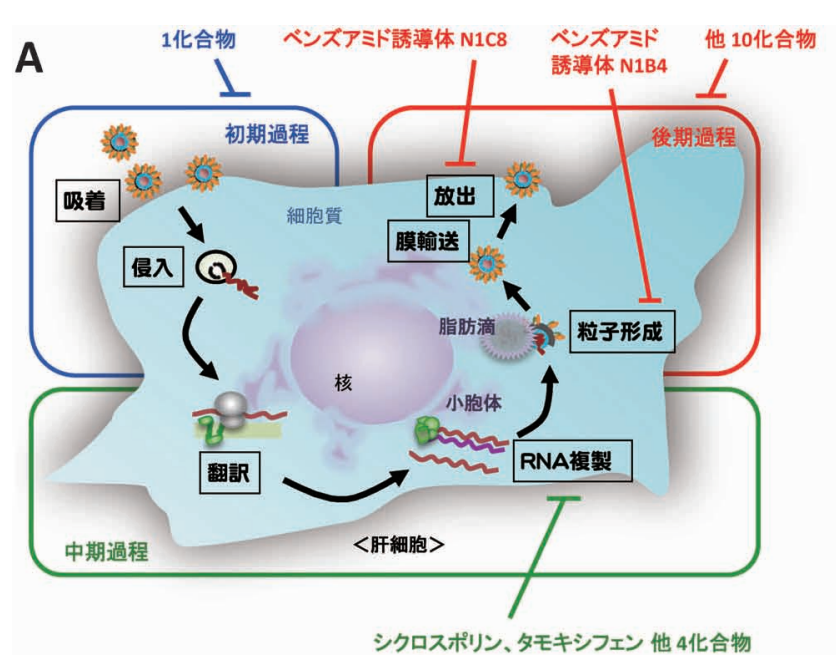

B レプリコン (中期過程)

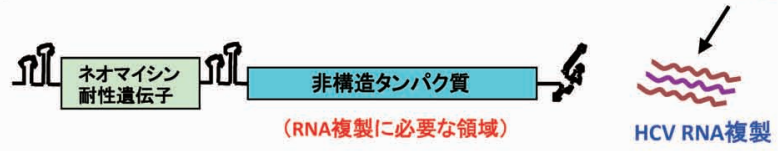

C HCVpp (初期過程)

エンベローフ + MLV Gag-Pol + luciferase

(粒子䔩造を担う領域)

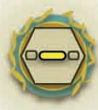

HCVシュード(偽)粒子

D HCV cc (HCV生活環全過程)

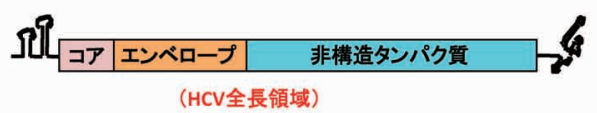

HCV粒子

Fig. 1. HCV Life Cycle and the Experimental Systems Analyzing Each Step in the Life Cycle

(A) Scheme of the HCV life cycle. HCV attaches to target hepatocytes to enter into the cytoplasm. After uncoating, HCV genome RNA is translated to viral proteins in the ribosome. Produced viral nonstructural proteins replicate viral genome RNA in the viral replication complex formed around the endoplasmic reticulum. Viral proteins and genome RNA assemble together mainly on the surface of the lipid droplets. The formed viral particles traffic through the secretory pathway to release outside of the cells. Each step of the life cycle including attachment, entry (tentatively defined as the "early step"), translation, RNA replication (as the "middle step"), assembly, trafficking, and release (as the "late step") can be a target of anti-HCV agents. Cyclosporin A, tamoxifen, and four additional compounds target the RNA replication, while bezamide derivatives N1C8 and N1B4 blocked the trafficking/release and assembly, respectively. Ten other compounds inhibited the late step, while one compound blocked the early step. (B) HCV replicon system. A chimeric RNA expressing the viral nonstructural protein region and the neomycin resistant gene in place of the viral structural region can produce the $\mathrm{HCV}$ replicon, which autonomously replicates in hepatoma Huh-7 cells. (C) HCV pseudoparticle (HCVpp) system. Transfection with the expression plasmids for HCV envelope proteins, murine leukemia virus (MLV) Gag-Pol, and the luciferase into 293T cells can produce HCVpp, which carries HCV envelope proteins outside of the MLV capsid and genome RNA encoding the luciferase. This system can evaluate HCV envelope-mediated attachment/entry by monitoring luciferase activity. (D) HCV-producing cell culture (HCVcc) system. A whole genome of HCV RNA introduced into Huh-7 cells can produce infectious HCV particles, which support the whole HCV life cycle.

部を再現する細胞培養系を用いて HCV 増殖を阻害 する低分子化合物をスクリーニングする。得られた 化合物をプローブに用いて HCV 増殖を制御する分 子メカニズムを解析することができる。 また得られ た化合物は抗ウイルス剤のリード化合物になり得る ことから，これを至適化することにより抗 $\mathrm{HCV}$ 剂 開発を目指す。すなわち化学遺伝学的手法をウイル ス学の解析に取り入れた方法論である。ここではま ずこのような手法が最も成功した代表例の 1 つを挙 げる.

われわれはまず翻訳〜 RNA 複製を含む $\mathrm{HCV}$ 生 活環中期過程に着目し，これを阻害する低分子化合 物のスクリーニングを行った. ライブラリーには様 々な構造や生理活性を持つ市販の化合物を用いた。 その結果多くの化合物の中から, HCV レプリコン システムにおける HCV RNA 量をそれぞれ約 1/ $500,1 / 50$ に強く減少させるものが, シクロスポリ ン及びタモキシフェンであった. ${ }^{14,15)}$ 以下に述べる ようにその後の解析によってシクロスポリンは RNA 複製に係わる複製複合体の機能を修飾し，一 方タモキシフェンは複製複合体の形成を標的とする
ことが明らかとなった。

\section{6. シクロフィリンによる RNA 複製制御}

シクロスポリンの様々な誘導体を用いて構造活性 相関を検討した。一般的にシクロスポリンには主に シクロフィリン, カルシニューリン, 細胞膜トラン スポーターの 3 つの標的分子が存在するが, 抗 $\mathrm{HCV}$ 効果はシクロフィリン阻害効果プロファイル と非常によく一致していることが判明した. ${ }^{16-18) ~ つ ~}$ まりシクロスポリンはシクロフィリン阻害により抗 $\mathrm{HCV}$ 作用を発揮していると考えられた。実際に内 在性シクロフィリンを siRNA でノックダウンする ことにより HCV RNA 量が低下することから， シ クロフィリンは HCV RNA 複製を制御しているこ とが示唆された。ここで詳しくは述べないが分子生 物学的解析によりシクロフィリンは HCV RNA ポ リメラーゼであるNS5B タンパク質に結合し，そ の基質 RNA との親和性を上昇させることが示唆さ れた。このように低分子化合物を用いることで HCV RNA 複製に必須の宿主因子が明らかとな り，またこれは抗 $\mathrm{HCV}$ 剂の創薬標的となると考え られた. 
7. シクロスポリンをプラットフォームとした抗 $\mathrm{HCV}$ 剂の開発

シクロスポリンはインターフェロンと併用するこ とにより相乗的に抗 $\mathrm{HCV}$ 作用を増強させたこと, また薬剤耐性ウイルス出現頻度がプロテアーゼ阻害 剤などに比較して著しく低いことより有望なリード 化合物と考えられた。 ${ }^{18,19)}$ その後欧米の製薬企業に よりシクロスポリンのカルシニューリン抑制活性を 欠失し，シクロフィリン阻害活性を上昇させた alisporivir (Debio 025), NIM811, SCY-635 に関して はそれぞれ慢性 C 型肝炎治療を目的とした臨床試 験が行われており，現在臨床試験第 III 相，第 II 相 まで進んでいる（Table 1). 20,21）このように基礎ウ イルス学研究から創薬に貢献できる成果を得ること が可能となった。

\section{8. エストロゲン受容体による複製複合体形成制} 御

一方タモキシフェンの標的タンパク質としてはエ ストロゲン受容体が知られるが，これが HCV
RNA ポリメラーゼ NS5B と結合していること，エ ストロゲン受容体が HCV RNA 複製を増強させて いることが，タンパク質結合アッセイ及び RNAi 法により示された. ${ }^{15)}$ またシクロフィリンとは異な り，エストロゲン受容体は NS5B の RNA 結合能で はなく，その複製複合体へのリクルートを促進させ ることが示唆された。なお深澤らにより，タモキシ フェンは RNA 複製に加えて HCV 侵入も阻害する ことが報告された. ${ }^{22)}$ ただしタモキシフェンはシク ロスポリンに比較して抗 HCV 効果がマイルドであ り，また細胞毒性もより高いことから，いまだ臨床 開発へは至っていない。

\section{9. 臨床開発中の抗 HCV 剂の現状}

以上のように HCV レプリコンシステムを用いる ことにより，HCV 翻訳/RNA 複製を阻害する低分 子化合物をスクリーニングすることができ，またそ の分子メカニズムを明らかにすることもできた.

Table 1 に現在臨床開発中の薬剤の概要を示した. ${ }^{20)}$ ウイルスタンパク質を直接阻害するプロテアーゼ阻

Table 1. Anti-HCV Agents under Clinical Development

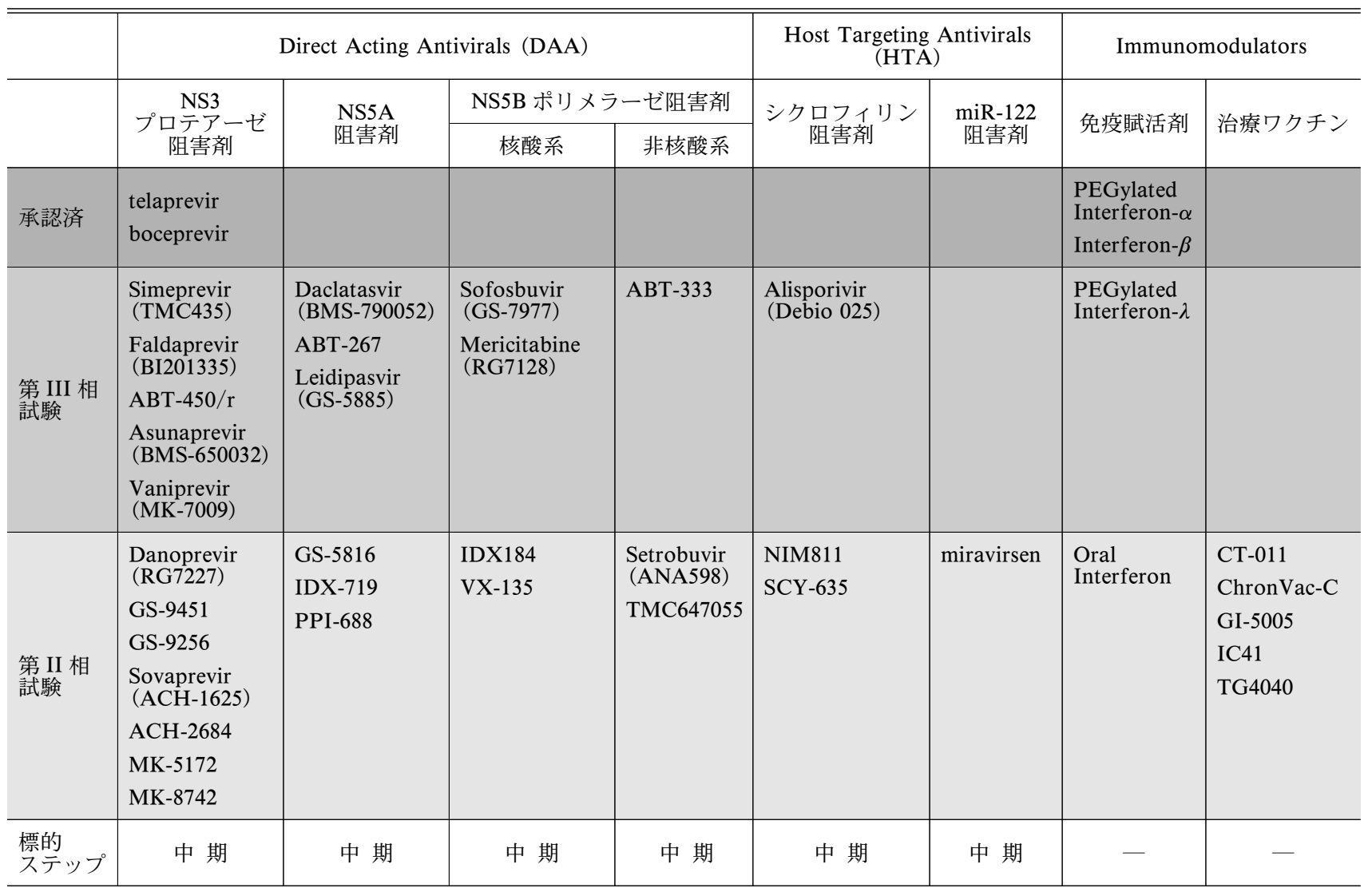

Anti-HCV agents can be classified as direct acting antivirals (DAA), host targeting antivirals (HTA), and immunomodulators. This table shows the agents under clinical trial phase II and III as well as approved agents. 
害剂, ポリメラーゼ阻害剂（核酸型，非核酸型）, NS5A 阻害剂は直接標的型抗ウイルス剤 direct acting antivirals（DAA）と総称され, 現在 30 剂以上 の薬剤が臨床試験で評価を受けている。 一方シクロ フィリン阻害剂を含めたマイクロ RNA-122 阻害剂 などは宿主標的型抗ウイルス剤 host targeting antivirals（HTA）として，HCV 遺伝子型により効果 が左右され，また薬剤耐性ウイルス出現が高頻度な 傾向にあるDAA の性質を補完する薬剤群として開 発が期待されている.

ここで着目すべき点として，これまでの DAA 及 び HTA はほぼすべて HCV のプロセシングや RNA 複製などの HCV 生活環中期過程を阻害する ものであり, 臨床開発初期段階にある侵入阻害剂を 除いては, HCV 生活環中の薬剤標的ステップはご く限られたものとなっている (Table 1). 抗 HCV 剂開発において, HCV 生活環中期過程以外, 特に これまでここを阻害する薬剤が開発されていない後 期過程は創薬の標的となり得るのであろうか? わ れわれはこの点に着目してさらに解析を行った。

\section{HCV 粒子産生系を用いた HCV 産生阻害剂} の同定

前述のように 2005 年になって HCV シ システム が開発されたが，これはそれまで不可能であった $\mathrm{HCV}$ 生活環すべての解析を可能とするものであ る. ウイルスを Huh-7 細胞及びその亜株に感染す ることにより, 細胞内で増殖, 子孫ウイルスが培養 上清に放出され, これが新たな非感染細胞に感染し $\mathrm{HCV}$ 感染細胞が経時的に増加していくという，い わゆるウイルス感染培養実験を HCV でも可能にす る発見であった。これにより $\mathrm{HCV}$ 生活環すべてを 標的として細胞ベースの抗ウイルス剤のスクリーニ ング及びその機能解析を行うことができる，われわ れはこの HCV cc システムを用いて，HCV 粒子産 生を阻害する低分子化合物の同定を行った.

市販化合物ライブラリーより, HCV 粒子の感染 性を $1 / 3$ 以下に減少させるものとして 20 化合物が 得られた。これらのうち GW6471, z-guggulsterone, fulvestrant はそれぞれ核内ホルモン受容体 PPAR $\alpha$, FXR, ER 阻害活性を有することが知られている が，一方でこれまでに HCV RNA 複製にはこれら の核内ホルモン受容体が重要であることが報告され ている. ${ }^{15,23,24)}$ つまり既報の HCV 複製機構を阻害
する化合物が確かに得られており，今回用いた HCV cc 実験系が抗 HCV 剛同定に機能しているこ とを示唆している. 残りの 17 化合物に関して次に, $\mathrm{HCV}$ 生活環のどのステップを阻害しているのかを 解析した。 そのために HCVpp システム及びレプリ コンシステムを用い，それぞれの化合物が中期及び 初期過程に影響を与えるかどうかを調べた。その結 果， 1 化合物が HCVpp 感染により発現するルシフ エラーゼ活性を有意に低下させ，4化合物が $\mathrm{HCV}$ レプリコン複製に伴うルシフェラーゼ活性を低下さ せ [Fig. 1(A)]，これらはそれぞれ HCV 生活環初 期過程及び中期過程を標的とすると考えられた。 まり残りの 12 化合物は HCV 後期過程を阻害する と考えられた。

\section{HCV 放出阻害剤, 粒子形成阻害剤の同定}

得られた 12 化合物のうちの 1 つでベンズアミド 骨格を有する N1C8 化合物に関して解析した。 $\mathrm{HCV}$ 感染細胞に N1C8 を処理した場合, 培養上清 中の HCV 感染力価は用量依存的に $1 / 10$ 以下まで 低下したが，このとき細胞内で粒子形成された $\mathrm{HCV}$ の感染力価には影響を与えなかった。また感 染性 HCV の放出効率は N1C8 処理により $1 / 10$ 以 下に低下していた。 また分泌された宿主アルブミン 及びアポリポタンパク質には大きな影響を与えなか つたことより，N1C8 は HCV 膜輸送/放出を特異 的に阻害すると考えられた。 また N1C8 処理により HCV core がゴルジに蓄積したことから，これは形 成された HCV 粒子がゴルジを経る分泌経路過程を 阻害していると考えられた。この化合物を HCV 感 染細胞に持続的に処理した場合, HCV 感染細胞の 経時的な広がりが阻害されることが判明した。これ まで特に慢性疾患を引き起こすウイルスに対する抗 ウイルス剤において放出阻害剂を開発した例はほぼ 存在しなかったが, 本研究結果よりウイルス放出が 一般的に抗ウイルス剤の創薬の標的となり得る可能 性が考えられた。

また得られた後期過程阻害剂 12 化合物のうち別 のベンズアミド誘導体であるN1B4 化合物に関して 解析を行った，興味深いことに，この化合物は培養 上清中だけではなく細胞内で粒子形成された $\mathrm{HCV}$ 感染力価も有意に低下させたことより，N1B4 は $\mathrm{N} 1 \mathrm{C} 8$ とは異なり粒子形成を阻害すると考えられ た。このように HCV cc を用いたスクリーニングよ 
り，異なる作用点を持つ後期過程阻害剂が得られ

た. 今後これらの化合物の作用点をさらに検討する ことにより, $\mathrm{HCV}$ 生活環後期過程の分子機構の一 端が明らかになると期待される。

12. おわりに

以上のように HCV レプリコンシステム及び $\mathrm{HCV} c c$ システムを用いて HCV 複製増殖を阻害す る低分子化合物を同定することができた。またこれ ら低分子化合物をプローブに用いて HCV 複製増殖 の分子メカニズムを同定することが可能となった.

このようにいわゆる化学遺伝学的手法をウイルス学 の解析に用いることによって，ウイルス複製の分子 機構だけでなく，新たな抗ウイルス剂の開発が期待 でき，アカデミアからの創薬という観点において魅 力的な解析法であると考えられる.

またこのような解析は HCV だけでなく, 原理的 には様々なウイルスに対して応用することができそ うである。われわれは B 型肝炎ウイルスに関して も同様の解析を行っており, 新たな抗ウイルス剤の 標的ステップが明らかになりつつある.

謝辞 本研究を遂行するにあたりご協力頂いた 京都大学ウイルス研究所ヒトがんウイルス研究分野 (下遠野研究室)，国立感染症研究所ウイルス第二部 の夕なさまを始め, 様々な共同研究者, 研究協力者 の先生方に深謝いたします。また本研究は科学研究 費補助金，厚生労働科学研究費補助金のサポートに より実施されたものです。

\section{REFERENCES}

1) Alter M. J., Kruszon-Moran D., Nainan O. V., McQuillan G. M., Gao F., Moyer L. A., Kaslow R. A., Margolis H. S., N. Engl. J. Med., 341, 556-562 (1999).

2) McHutchison J. G., Gordon S. C., Schiff E. R., Shiffman M. L., Lee W. M., Rustgi V. K., Goodman Z. D., Ling M. H., Cort S., Albrecht J. K., N. Engl. J. Med., 339, 1485-1492 (1998).

3) Pawlotsky J. M., Hepatology, 53, 1742-1751 (2011).

4) Ploss A., Evans M. J., Curr. Opin. Virol., 2, 14-19 (2012).

5) Pineiro D., Martinez-Salas E., Viruses, 4,
2233-2250 (2012).

6) Rai R., Deval J., Antiviral Res., 90, 93-101 (2011).

7) Popescu C. I., Rouille Y., Dubuisson J., Viruses, 3, 2238-2254 (2011).

8) Lohmann V., Korner F., Koch J., Herian U., Theilmann L., Bartenschlager R., Science, 285, 110-113 (1999).

9) Bartosch B., Dubuisson J., Cosset F. L., J. Exp. Med., 197, 633-642 (2003).

10) Hsu M., Zhang J., Flint M., Logvinoff C., Cheng-Mayer C., Rice C. M., McKeating J. A., Proc. Natl. Acad. Sci. USA, 100, 72717276 (2003).

11) Zhong J., Gastaminza P., Cheng G., Kapadia S., Kato T., Burton D. R., Wieland S. F., Uprichard S. L., Wakita T., Chisari F. V., Proc. Natl. Acad. Sci. USA, 102, 9294-9299 (2005) .

12) Wakita T., Pietschmann T., Kato T., Date T., Miyamoto M., Zhao Z., Murthy K., Habermann A., Krausslich H. G., Mizokami M., Bartenschlager R., Liang T. J., Nat. Med., 11, 791-796 (2005) .

13) Lindenbach B. D., Evans M. J., Syder A. J., Wolk B., Tellinghuisen T. L., Liu C. C., Maruyama T., Hynes R. O., Burton D. R., McKeating J. A., Rice C. M., Science, 309, 623-626 (2005).

14) Watashi K., Hijikata M., Hosaka M., Yamaji M., Shimotohno K., Hepatology, 38, 12821288 (2003).

15) Watashi K., Inoue D., Hijikata M., Goto K., Aly H. H., Shimotohno K., J. Biol. Chem., 282, 32765-32772 (2007).

16) Watashi K., Ishii N., Hijikata M., Inoue D., Murata T., Miyanari Y., Shimotohno K., Mol. Cell, 19, 111-122 (2005).

17) Ishii N., Watashi K., Hishiki T., Goto K., Inoue D., Hijikata M., Wakita T., Kato N., Shimotohno K., J. Virol., 80, 4510-4520 (2006).

18) Goto K., Watashi K., Murata T., Hishiki T., Hijikata M., Shimotohno K., Biochem. Biophys. Res. Commun., 343, 879-884 (2006).

19) Goto K., Watashi K., Inoue D., Hijikata M., Shimotohno K., Cancer Sci., 100, 1943-1950 (2009) .

20) Schlutter J., Nature, 474, S5-S7 (2011).

21) Watashi K., Curr. Opin. Investig. Drugs, 11, 
213-224 (2010).

22) Murakami Y., Fukasawa M., Kaneko Y., Suzuki T., Wakita T., Fukazawa H., Microbes Infect., 15, 45-55 (2012).

23) Chang K. O., George D. W., J. Virol., 81,
9633-9640 (2007).

24) Rakic B., Sagan S. M., Noestheden M., Belanger S., Nan X., Evans C. L., Xie X. S., Pezacki J. P., Chem. Biol., 13, 23-30 (2006). 